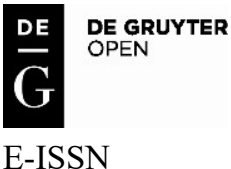

2450-8594

\title{
LIMIT ANALYSIS OF THIN-WALL METAL FRAMES TAKING INTO ACCOUNT THEIR FOUNDATIONS RIGIDITY
}

\author{
Piotr ALAWDIN ${ }^{1}$, Viktoryia PETRUSEVICH \\ University of Zielona Gora, Zielona Góra, Poland
}

\begin{abstract}
In this paper, the mathematical model of shakedown optimization problem of limit analysis for the thin-wall metal frames under variable quasi-static loads is presented. Authors assume the elastic-plastic flexural buckling in one plane without lateral torsional buckling behavior of members on conditions of the ideal elastic-plastic behaviour of the frames materials. According to Eurocodes requirements, the features of these frames taking into account rigidity of their foundations are described. There is problem with definition equivalent uniform moment factors for frames under variable quasi-static loads, because moment diagram is not constant. Classification of joints by stiffness was analyzed. The cases when the conditions of rigidity are not satisfied were described. The variants of solving tasks for thin-wall metal frames have been developed, for which there is a discrepancy between the classification by stiffness of the column base and the initial design model. It's demonstrated on the principle scheme of the iteration process. With the help of numerical example, the problems which deal with classification of joints by stiffness on the final step of the optimal design of the thin-wall metal frames were performed.
\end{abstract}

Keywords: limit and shakedown analysis, mathematical model, thin-wall metal frames, foundations rigidity

\footnotetext{
${ }^{1}$ Corresponding author: University of Zielona Gora, Faculty of Civil Engineering, Architecture and Environmental Engineering, Szafrana st 1, 65-516 Zielona Góra, Poland, e-mail: p.aliawdin@ib.uz.zgora.pl, tel.+48683282322
} 


\section{INTRODUCTION}

Up to date, classical optimization problems of metal structures are confined mainly with the 1 st and the 2 nd classes of cross-sections. But in practice, it is common to use the cross-sections of higher classes. A mathematical model for shakedown optimization problem for thin-wall metal frames, which elements are designed from 1 st to 4 th class cross-sections, under variable quasi-static loads is presented. The optimization of thin-wall metal frames under variable repeated loads and actions remains an important problem today. In reality, buildings are loaded with the variable repeated quasi-static loads and actions, which are arbitrary varying within known domain.

According to Eurocode requirements, the features of behaviour of TWM frames taking into account the rigidity of their foundations were described. The rotational stiffness of a joint is an important component in the classification of the column base rigidity. If the conditions of the rigidity classifications of the column base according to the initial design model are not satisfied, then the iterative process should be made. It can be a serious problem for the design process. With the help of numerical example, the problems which deal with classification of joints by stiffness on the final step of the design of TWM frames were demonstrated. The ways of solving these tasks were performed.

The example of such shakedown approach to the steel frames confined with 1st class cross-sections was published in a paper by Atkochiunas \& Venskus (2011); a shakedown limit analysis of the reinforced concrete frames has been done by Alawdin \& Bulanov (2014); an updated mathematical model for optimal shakedown analysis of plane reinforced concrete frames according to Eurocodes has been introduced by Alawdin \& Liepa (2015); shakedown optimization of thinwall metal structures under strength and stiffness constraint by Alawdin \& Liepa (2015).

\section{MATHEMATICAL MODEL OF OPTIMIZATION OF THE THIN-WALL METAL FRAMES}

Mathematical model in this paper is based on the hypothesis of small displacements the joints of constructions on conditional of the ideal elastic-plastic behaviour of the frames materials. Linear mathematical programing theory and finite elements method are used in order to design the mathematical model. The elastic-plastic flexural buckling in one plane without lateral torsional buckling behaviour of members is assumed.

The TWM frames structures are loaded by forces $F$ varying in the certain domain $\Omega(F)$. Limit forces are optimized here at shakedown, when load variation. Material, lengths and ratio of limit forces in all $i$-th elements, $i \in I$, are known. 
The problem of shakedown optimization of elastic-plastic system under loads $F$ varying in the certain domain $\Omega(F)$ is next: find $S^{0}$ and $S^{r}$ from

$$
\begin{gathered}
T^{T} S^{0} \rightarrow \min , \\
\varphi_{i}\left(S_{i}^{e l}(F), S_{i}^{r}, S_{i}^{0}\right) \leq 0, \\
F \in \Omega_{F}, S^{0} \geq 0, \\
A E_{p} S^{r}=0, \\
E_{p}=\operatorname{diag} E_{p i}, i \in I, \\
S_{i}^{0}=\left[\begin{array}{l}
M_{i}^{0} \\
N_{i}^{0} \\
V_{i}^{0}
\end{array}\right] ; S_{i}^{e l}=\left[\begin{array}{l}
M_{i}^{e l} \\
N_{i}^{e l} \\
V_{i}^{e l}
\end{array}\right] ; S_{i}^{r}=\left[\begin{array}{l}
m_{i}^{r} \\
n_{i}^{r} \\
v_{i}^{r}
\end{array}\right] .
\end{gathered}
$$

Where: $T^{T} S^{0}$ - criterion of optimization of construction weight; $T^{T}$ - a vector of weight coefficients; $S^{0}$ - a vector of limit internal forces in the cross-sections; $S^{e l}$ a vector of elastic internal forces; $S^{r}$ - a vector of the of residual internal forces; $A$ - matrix of equilibrium equations; $E_{p}$ - a diagonal matrix that determines the presence (or absence) of residual internal forces $S_{i}^{r}$ in the cross sections of the $i$ th elements of classes 1,2 (or 3,4), respectively, $i \in I ; I$ - a set of the designed cross-sections.

A diagonal submatrix $E_{p i}$ reads here as follows:

$$
E_{p i}=\left[\begin{array}{c}
\operatorname{diag}\left[\begin{array}{l}
1 \\
1 \\
1
\end{array}\right] \text { for class } 1 \text { and } 2 \\
\operatorname{diag}\left[\begin{array}{l}
0 \\
0 \\
0
\end{array}\right] \text { for class } 3 \text { and } 4
\end{array}\right] .
$$


In the case when it's necessary to obtain the optimal solution of the task quickly, one can use a simplified mathematical model: find limit parameter $M^{0}$ and vector of residual bending moments $m$ from

$$
\begin{gathered}
M^{0} \rightarrow \text { min, } \\
k_{y y}\left(M_{i}^{+}+E_{p i} m_{i}\right) \geq \mu_{i} M^{0}, \\
k_{y y}\left(M_{i}^{-}-E_{p i} m_{i}\right) \geq-\mu_{i} M^{0}, \\
A E_{p} m=0, \\
E_{p}=\operatorname{diag} E_{p i}, i \in I, \\
E_{p i}=\left[\begin{array}{l}
\operatorname{diag}[1] \text { for class } 1 \text { and } 2 \\
\operatorname{diag}[0] \text { for class } 3 \text { and } 4
\end{array}\right] .
\end{gathered}
$$

Where $\mu=\left[\mu_{i}\right]$ - the given vector of ratio of limited bending moments; $m=\left[m_{i}\right]$ vector of residual bending moments $m_{i} ; M_{i}^{-}, M_{i}^{+}$- extremal elastic bending moments in the cross sections of the $i$-th elements, $i \in I$.

In mathematical model (2.1) - (2.5) can be included not only the external forces (loads), but any other actions, for example, kinematic distortions or thermal actions.

\section{MEMBER STABILITY CHECK}

Members which are subjected to combined bending and axial compression should satisfy (6.3.3 [2]):

$$
\frac{N_{E d}}{\chi_{y} N_{R d}}+k_{y y} \cdot \frac{M_{y, E d}}{M_{y, R k}} \leq 1,
$$

where $k_{y y}$ - interaction factors for members not susceptible to torsional deformations; $\chi$ - are the reduction factors due to flexural buckling; internal forces $N_{E d}, M_{E d}$ in the cross sections of the elements are found in the process of solving of problem (2.1) - (2.8) or (2.9) - (2.14).

For plastic cross-sectional properties (class 1 and 2) limit internal forces $N_{R d}$ and $M_{R d}$ are determined as: 


$$
N_{R d}=\frac{A \cdot f_{y}}{\gamma_{M 1}} ; M_{R d}=\frac{W_{y} \cdot f_{y}}{\gamma_{M 1}} .
$$

For elastic cross-sectional properties (class 3 and 4) limit internal forces $N_{R d}$ and $M_{R d}$ are determined as:

$$
N_{R d}=\frac{A_{e f f} \cdot f_{y}}{\gamma_{M 1}} ; M_{R d}=\frac{W_{y, e f f} \cdot f_{y}}{\gamma_{M 1}} .
$$

For plastic cross-sectional properties (class 1 and 2) interaction $k_{y y}$ factor should satisfy:

$$
k_{y y}=C_{m y}\left(1+0,6 \overline{\lambda_{y}} \frac{N_{E d}}{\chi_{y} N_{R d}}\right) \leq C_{m y}\left(1+0,6 \frac{N_{E d}}{\chi_{y} N_{R d}}\right) .
$$

For elastic cross-sectional properties (class 3 and 4) interaction $k_{y y}$ factor should satisfy:

$$
k_{y y}=C_{m y}\left(1+\left(\overline{\lambda_{y}}-0,2\right) \frac{N_{E d}}{\chi_{y} N_{R d}}\right) \leq C_{m y}\left(1+0,8 \frac{N_{E d}}{\chi_{y} N_{R d}}\right) .
$$

There is a problem with definition equivalent uniform moment factors $C_{m y}$ for frames under variable quasi-static loads, because moment diagram is not constant. It's difficult to predict the exact value of this factor. So it's necessary to accept here the extremum value of $C_{m y}$ in order to predict all cases of distributions of moments.

\section{CHECK OF COLUMN BASE UNDER AXIAL FORCE AND MOMENT}

The design moment resistance $M_{j, R d}$ of a column base subject to combined axial force and moment should be determined using the method EN 1993-1-8 [3], where the contribution of the concrete portion just under the column web (T-stub) to the capacity is omitted. One of the following cases of the column base behavior can be reveiwed:

$\checkmark$ left side in tension, right side in compression;

$\checkmark$ left side in tension, right side in tension; 
$\checkmark$ left side in compression, right side in tension;

$\checkmark$ left side in compression, right side in compression.

The applied design moment $M_{j, R d}$ should satisfy:

$$
\frac{M_{j, E d}}{M_{j, R d}} \leq 1 .
$$

If the condition of formulae (4.1) is satisfied, then should determine the kind of column base by stiffness.

Column bases may be classified as:

1) rigid;

2) nominally pinned;

3) semi-rigid.

Iteration process is need in the case, when the rigidity of the column base connection is different in comparison with the initial design model. Principle scheme (see Figure 1) demonstrates some ways of solving this task.

\section{EXAMPLE OF SHAKEDOWN ANALYSIS OF TWM FRAME TAKING INTO ACCOUNT FOUNDATIONS RIGIDITY}

As an example, four-store TWM plane frame was considered (see Fig. 2). This frame was subjected to five independent loads: horizontal load $F_{1}, F_{2}, F_{3}, F_{4}$ and vertical load $F_{5}$. The structures are designed from members of cross-sectional Classes 1, 2 and 4. The column base connections are assumed as rigid. Here is assumed a monolithic bearing post foundation. The ratio of limited bending moments and element's rigidity are shown in Table1.

Table 1 . The ratio of limited bearing moments and element's rigidity

\begin{tabular}{|c|c|c|}
\hline $\begin{array}{c}\text { Class of cross- } \\
\text { section }\end{array}$ & $\begin{array}{c}\text { The ratio of limited bending } \\
\text { moments } \mu\end{array}$ & The ratio of rigidity $k$ \\
\hline Class 1 & 2 & 2 \\
\hline Class 2 & 1,8 & 1,8 \\
\hline Class 3 & 1,2 & 1,2 \\
\hline Class 4 & 1 & 1 \\
\hline
\end{tabular}




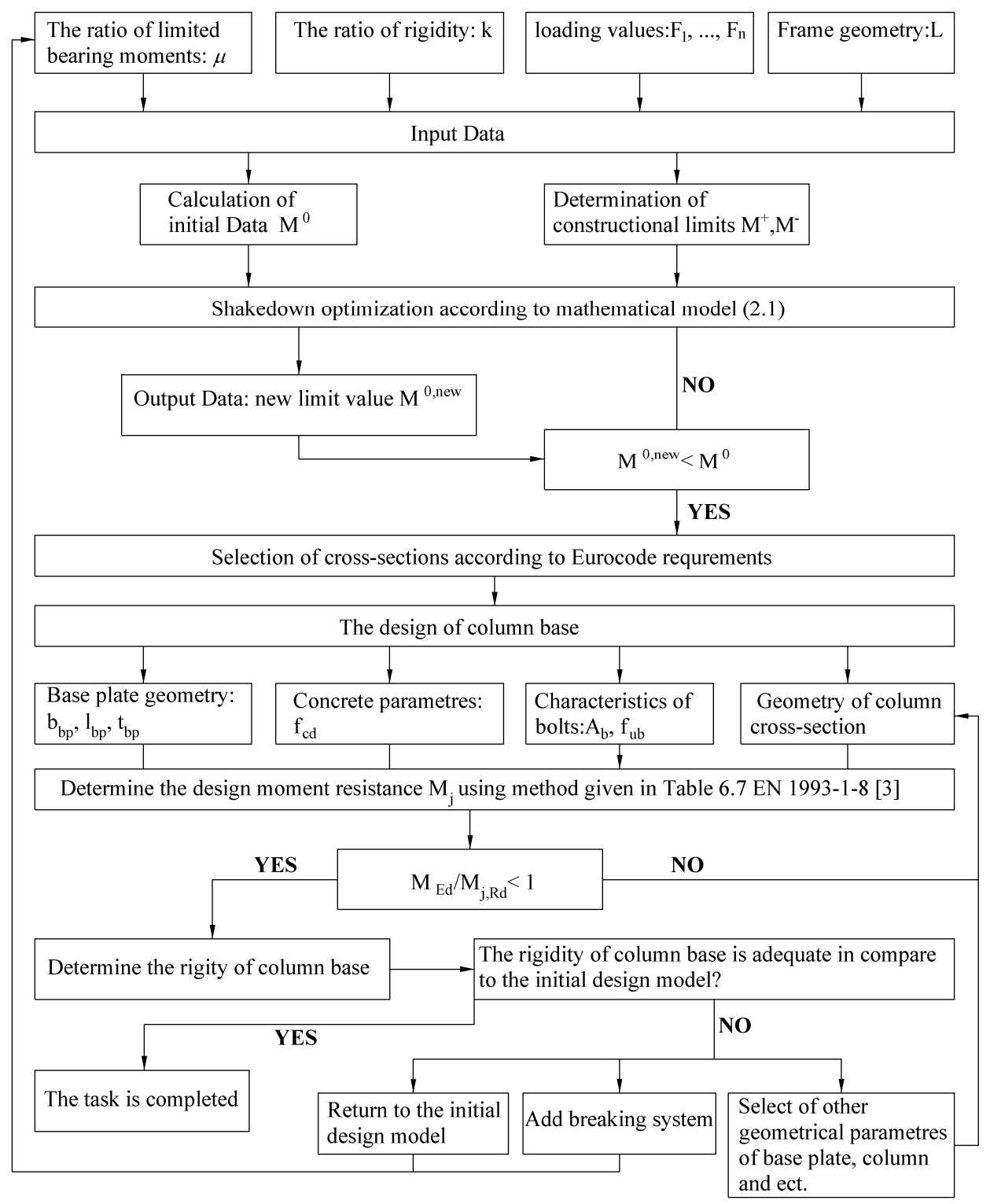

Fig. 1. Principle scheme of the iteration proces 


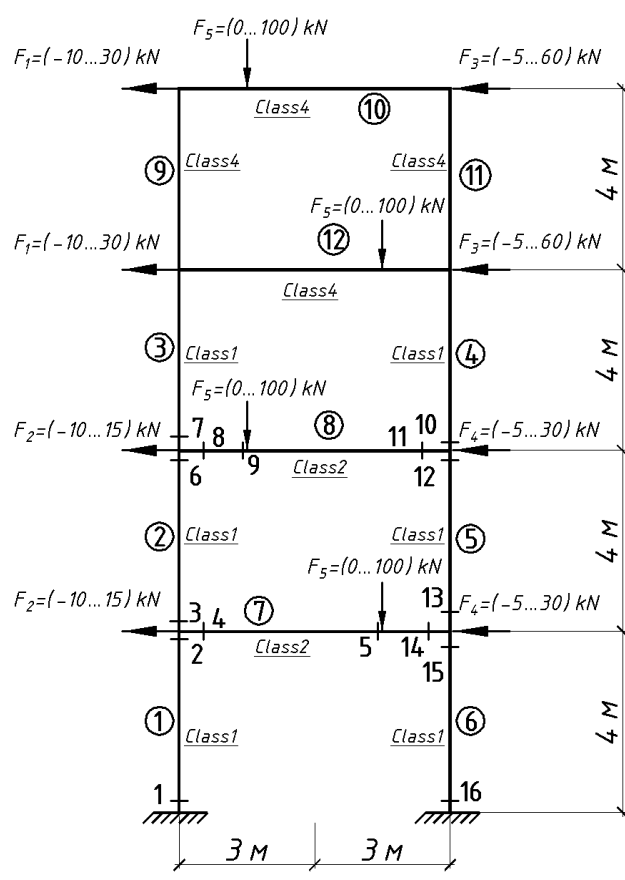

Fig. 2. Loading scheme a)

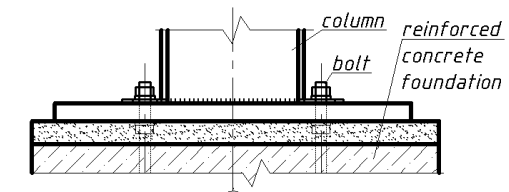

b)
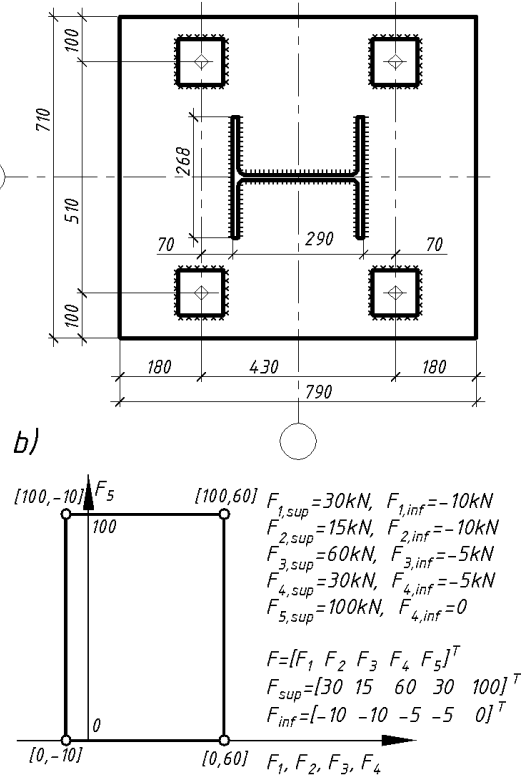

Fig. 3. a) Column base connections with foundation b) Loading locus

There are four loading combinations in total. Load combinations are shown in a Table 2 .

The conditions of elastic-plastic design of the task are written according to the a simplified mathematical model (2.9)-(2.14). The parameter of the limit bending moment $M^{0}$ and the residual moments $m_{i}$ are unknown. These parameters were found using the software Mathematica. Optimal limit bending moment $\mathrm{M}^{0}=227,08 \mathrm{kNm}$ (see Fig. 6) was obtained after summation of elastic bending moment diagram (see Fig. 5) and residual bending moments diagram (see Fig. 4.) Difference between elastic and optimal limit moments is $13,6 \%$. 
Table 2. Load combinations

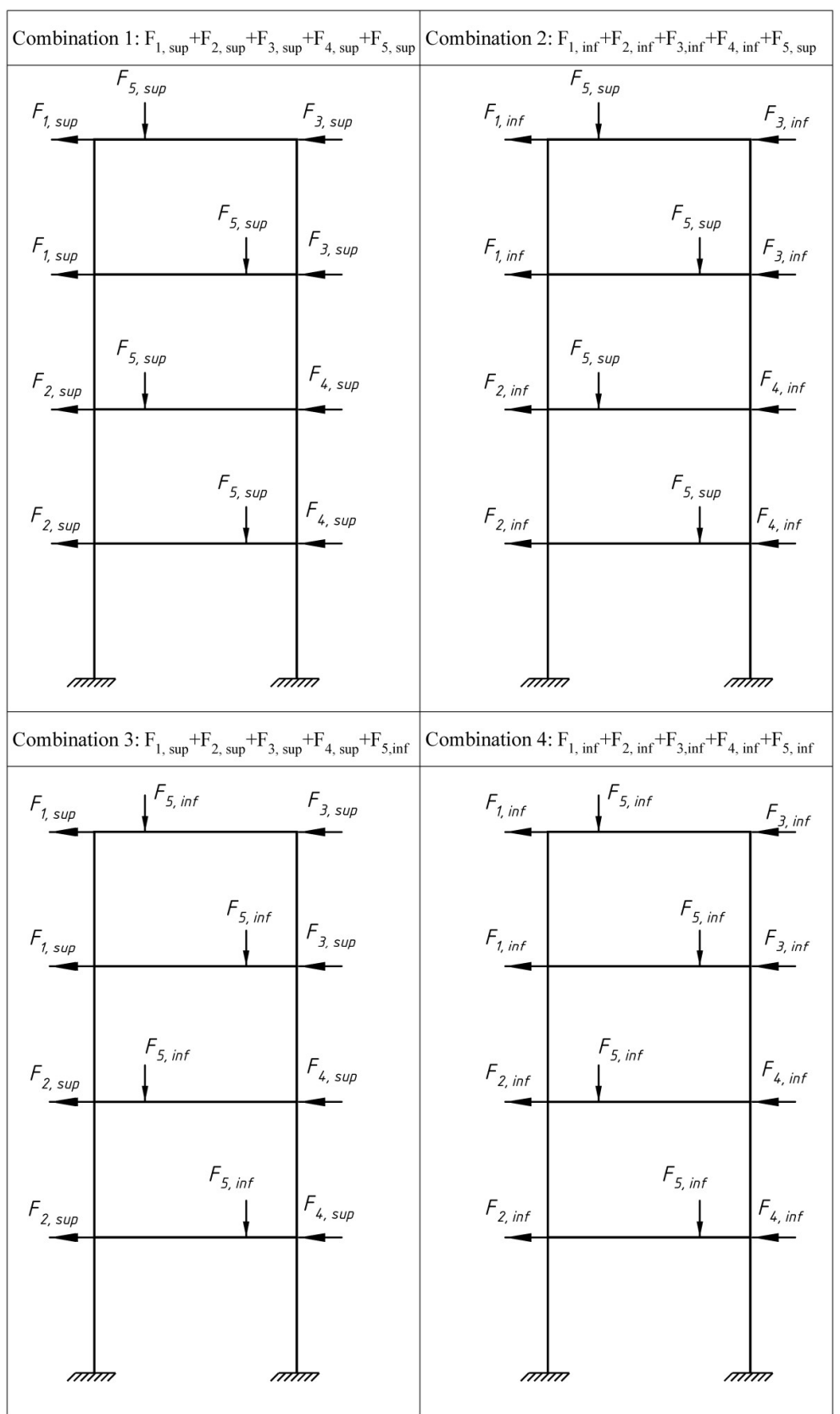




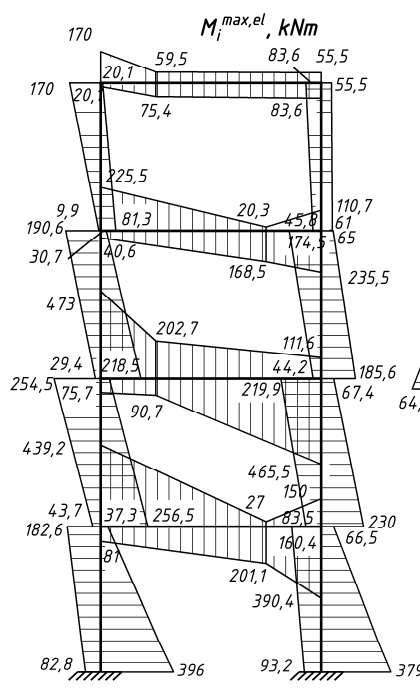

Fig. 4. Elastic bending moments $M_{i}$ distributions scheme

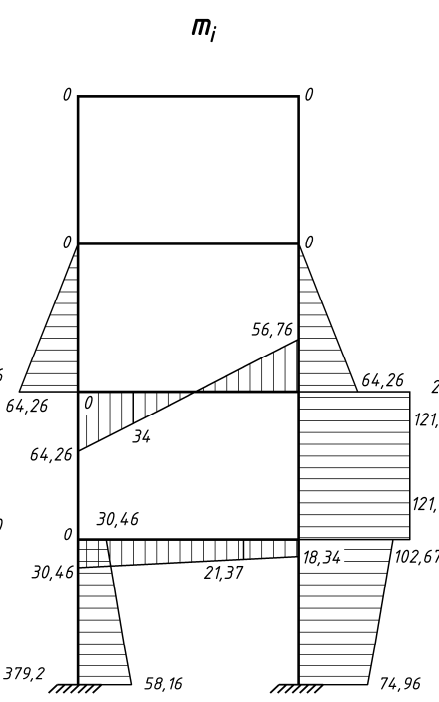

Fig. 5. Residual bending moments $m_{i}$ distributions

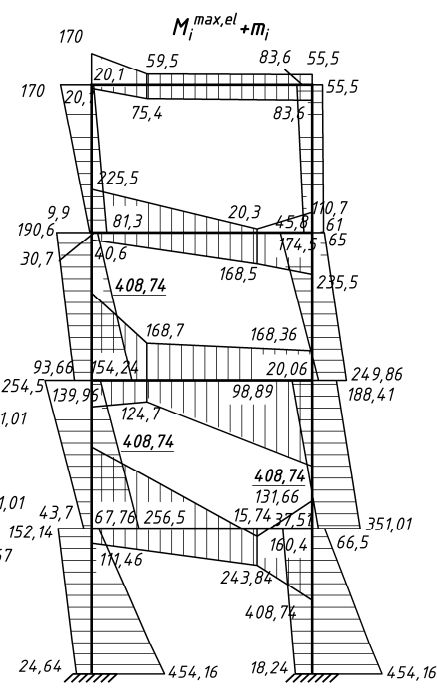

Fig. 6. Bending moments $M_{i}$ distributions taking into account residual bending moments $m_{i}$

According to the optimal solution, the cross-sections of the elements were designed according to requirements EN 1993-1-3 [1] and EN 1993-1-1 [2]. Members of the frame structure are designed from standard rolled IPE or HE cross-sections. Optimal cross-sectional values of each class are provided in Table 3.

Table 3. Cross-sections of TWM frame

\begin{tabular}{|c|c|c|c|c|c|c|c|c|}
\hline $\begin{array}{l}\text { № } \\
\text { El. }\end{array}$ & Class & $\begin{array}{l}M_{0}, \\
\mathrm{kNm}\end{array}$ & $\begin{array}{l}N_{\max }, \\
\mathrm{kN}\end{array}$ & $\begin{array}{l}\text { Cross } \\
\text { section }\end{array}$ & $A, \mathrm{~cm}^{2}$ & $\begin{array}{l}W_{p l}, \\
\mathrm{~cm}^{3}\end{array}$ & $\begin{array}{l}N_{R d}, \\
\mathrm{kN}\end{array}$ & $\begin{array}{l}M_{p l, R d}, \\
\mathrm{kNm}\end{array}$ \\
\hline 1 & \multirow{6}{*}{ I } & 454,2 & $-921,9$ & HE260M & 219,6 & 2524 & 5160,6 & 921,9 \\
\hline 2 & & 256,5 & $-430,9$ & HE220M & 149,4 & 1419 & 3510,9 & 333,5 \\
\hline 3 & & 190,6 & $-215,2$ & HE280A & 97,3 & 1112 & 2286,6 & 261,3 \\
\hline 4 & & 249,9 & $-123,2$ & HE300A & 112,5 & 1383 & 2643,8 & 325,0 \\
\hline 5 & & 351,0 & $-167,9$ & HE320A & 124,4 & 1628 & 2923,4 & 382,6 \\
\hline 6 & & 454,2 & $-988,9$ & HE260M & 219,6 & 2524 & 5160,6 & 988,2 \\
\hline 7 & \multirow{2}{*}{ II } & 408,7 & $-7,4$ & IPEA500 & 101 & 1946 & 2373,5 & 457,3 \\
\hline 8 & & 408,7 & $-8,9$ & IPEA500 & 101 & 1946 & 2373,5 & 457,3 \\
\hline 9 & \multirow{4}{*}{ V } & 170,0 & $-117,3$ & IPEA360 & 64 & 907 & 1504 & 213,1 \\
\hline 10 & & 170,0 & $-32,8$ & IPEA360 & 64 & 907 & 1504 & 213,1 \\
\hline 11 & & 83,6 & $-29,1$ & IPEA360 & 64 & 907 & 1504 & 213,1 \\
\hline 12 & & 225,5 & $-14,9$ & IPEA360 & 64 & 907 & 1504 & 213,1 \\
\hline
\end{tabular}




\subsection{The design of column base}

Required parameters for the design of column base are given in Table 4. Geometry of the column base is given on the Fig. 3 a).

Table 4. Characteristics of column base element's

\begin{tabular}{|c|c|c|c|}
\hline \multicolumn{2}{|l|}{ Characteristics of column } & \multicolumn{2}{|l|}{ Characteristics of base plate } \\
\hline $\begin{array}{l}\text { Design compression force } N_{E d} \text {, } \\
\mathrm{kN}\end{array}$ & $-921,9$ & Width, $b_{b p}, \mathrm{~mm}$ & 740 \\
\hline $\begin{array}{l}\text { Design bending moment, } \\
M_{y, E d,}, \mathrm{kNm}\end{array}$ & 454,2 & Yield strength, $f_{y, b p}, \mathrm{MPa}$ & 355 \\
\hline Depth $h, \mathrm{~mm}$ & 290 & Thickness, $t_{b p}, \mathrm{~mm}$ & 50 \\
\hline Width $b, \mathrm{~mm}$ & 268 & Length, $l_{b p}, \mathrm{~mm}$ & 790 \\
\hline Web thickness $t_{w}, \mathrm{~mm}$ & 18 & \multicolumn{2}{|c|}{ Characteristics of concrete C30/37 } \\
\hline Flange thickness $t_{f}, \mathrm{~mm}$ & 32,5 & $\begin{array}{l}\text { Design compressive } \\
\text { strength } f_{c d}, \mathrm{MPa}\end{array}$ & 17 \\
\hline Root radius $r, \mathrm{~mm}$ & 24 & \multicolumn{2}{|l|}{ Characteristics of bolts } \\
\hline $\begin{array}{l}\text { Plastic modulus y-y axis } W_{p l, y} \text {, } \\
\mathrm{mm}^{3}\end{array}$ & 2524 & Diameter, $d, \mathrm{~mm}$ & 48 \\
\hline Area $A, \mathrm{~mm}^{2}$ & 219,6 & Stress area, $A_{b}, \mathrm{~mm}^{2}$ & 1473 \\
\hline Yield strength $f_{y}, \mathrm{MPa}$ & 355 & $\begin{array}{l}\text { Ultimate tensile strength of } \\
\text { the bolt, } f_{u b}, \mathrm{MPa}\end{array}$ & 830 \\
\hline
\end{tabular}

In this case the right side of column base in tension, the left side in compression The design forces on the T-stubs are: right flange (T-stub 3) - tension, left flange (T-stub 1) - compression. Therefore,

$$
\begin{aligned}
& F_{T, r, E d}=-\frac{N_{E d} \cdot z_{C, r}}{z}+\frac{M_{y, E d}}{z}=\frac{-921,9 \cdot 0,12875}{0,34375}+\frac{454,16}{0,34375}=975,9 \mathrm{kN} ; \\
& F_{c, l, E d}=-\frac{N_{E d} \cdot z_{T, 1}}{z}-\frac{M_{y, E d}}{z}=-\frac{921,9 \cdot 0,215}{0,34375}-\frac{454,16}{0,34375}=-1897,8 \mathrm{kN} .
\end{aligned}
$$

The design compression resistance $F_{C, l, R d}$ of the left side of the joint should be taken as the smaller value of:

- the concrete in compression under the left column flange $F_{c, p l, R d}(6.2 .6 .9)$ [3];

- the left column flange and web in compression $F_{c, f c, R d}(6.2 .6 .7)$ [3].

$$
\begin{aligned}
& F_{c, p l, R d}=F_{C, R d}=f_{j d} l_{e f f, 1} b_{e f f, 1}=17 \cdot 10^{6} \cdot 0,528 \cdot 0,2925=2625,5 \mathrm{kN} ; \\
& F_{c, f c, R d}=F_{c, f b, R d}=\frac{M_{c, R d}}{\left(h-t_{f b}\right)}=\frac{881,1}{0,29-0,0325}=3421,9 \mathrm{kN} .
\end{aligned}
$$


The design tension resistance $F_{T, I, R d}$ of the right side of the joint should be taken as the smallest values of the design resistance of following basic components:

- the column web in tension under the right column flange $F_{t, w c, R d}$;

- the base plate in bending under the right column flange $F_{t, p l, R d}$.

The design tension resistance of T-stub flange should be determined from Table 6.2. [3]. In cases where prying forces may not develop the design tension resistance of a $\mathrm{T}$-stub flange $\mathrm{F}_{\mathrm{T}, \mathrm{Rd}}$ should be taken as the smallest value for the two possible failure modes according to Table 6.2. [3].

Mode 1, $2 F_{T, 1-2, R d}=\frac{2 M_{p l, 1, R d}}{m}=\frac{2 \cdot 33,3 \cdot 10^{3}}{0,07}=991 \mathrm{kN}$;

Mode $3 F_{T, 3, R d}=\sum F_{t, R d}=2 \cdot 1100,3=2200,6 \mathrm{kN}$;

$F_{T, R d}=\min \left(F_{T, 1-2, R d}, F_{T, 3, R d}\right)=951,4 k N$.

The design moment resistance of the joint $M_{j, R d}$ is smaller than two presented further:

$$
\begin{aligned}
& \min \left\{\begin{array}{l}
\frac{F_{T, R d} \cdot z}{z_{C, r} / e-1}=\frac{991 \cdot 10^{3} \cdot 0,34375}{0,12875 / 0,49-1}=-462,2 \mathrm{kNm} ; \\
\frac{-F_{C, r, R d} \cdot z}{z_{T, 1} / e+1}=\frac{-2625,5 \cdot 10^{3} \cdot 0,34375}{0,215 / 0,49+1}=-627,2 \mathrm{kNm}
\end{array}\right. \\
& \frac{M_{E d}}{M_{j, R d}}=\frac{-454,16}{-462,2}=0,98
\end{aligned}
$$

Therefore, the design moment resistance of the joint is adequate.

\subsection{Classification of joint}

5.2.2.5 (2) [3] Column bases may be classified as rigid provided the following conditions are satisfied:

if $S_{j, \text { ini }} \geq \frac{30 E I_{c}}{L_{c}}=\frac{30 \cdot 210000 \cdot 10^{6} \cdot 3,131 \cdot 10^{-4}}{4}=493,1 \mathrm{MPa}$.

6.3.1 (5) [3] The rota1ional stiffness $S_{j}$ of a column base, for a moment $M_{j, E d}$ less than the design moment resistance $M_{j, R d}$ of the joint, may be obtained with sufficient accuracy from 6.3.4. [3]. The rotational stiffness, $S_{j}$ of a column base 
subject to combined axial force and bending moment should be calculated using the method given in Table 6.12 [2].

$$
\begin{aligned}
& S_{j, \text { ini }}=\frac{E z^{2}}{\mu\left(1 / k_{C, l}+1 / k_{T, r}\right)} \cdot \frac{e}{e+e_{k}}=\frac{210000 \cdot 10^{6} \cdot 0,34375^{2}}{2,87 \cdot(44,04+18,96)} \cdot \frac{0,49}{0,49-0,03}= \\
& =144,8 \mathrm{MPa}
\end{aligned}
$$

Therefore, $S_{j, i n i}=144,8<493,1 M P a$.

The condition is not satisfied, that's why column bases may not be classified as rigid; this column base is semi-rigid. The iterative process should be made according to principle scheme (see Fig. 1).

In this example, one can increase the geometry characteristics of base plate and use a welded I-beam instead of a rolling one. New characteristics of column base element's is given in the Table 5.

Table 5. New characteristics of column base element's

\begin{tabular}{|l|l|}
\hline Column characteristics & $\begin{array}{l}h=260 \mathrm{~mm} ; \quad b=240 \mathrm{~mm} ; t_{w}=16 \mathrm{~mm} ; t_{f}=38 \mathrm{~mm} ; \\
W_{p l, y}=2151,6 \mathrm{~cm}^{3} ; A=210 \mathrm{~cm}^{2} ; f_{y}=355 \mathrm{~N} / \mathrm{mm}^{2} .\end{array}$ \\
\hline Base plate characteristics & $b_{b p}=870 \mathrm{~mm} ; t_{b p}=60 \mathrm{~mm}, l_{b p}=790 \mathrm{~mm}$. \\
\hline Characteristics of bolts & $d=64 \mathrm{~mm}, A=2676 \mathrm{~mm}^{2}, f_{u b}=830 \mathrm{MPa}$. \\
\hline
\end{tabular}

The design moment resistance of the joint $M_{j, R d}$ is smaller than two presented further:

$$
\begin{aligned}
& \min \left\{\begin{array}{l}
\frac{F_{T, R d} \cdot z}{z_{C, r} / e-1}=\frac{1609,6 \cdot 10^{3} \cdot 0,311}{0,111 / 0,49-1}=-646,2 \mathrm{kNm} ; \\
\frac{-F_{C, r, R d} \cdot z}{z_{T, 1} / e+1}=\frac{-3253,8 \cdot 10^{3} \cdot 0,311}{0,2 / 0,49+1}=-722,8 \mathrm{kNm} ;
\end{array}\right. \\
& \frac{M_{E d}}{M_{j, R d}}=\frac{-454,16}{-646,2}=0,703 ; S_{j, \text { ini }}=370,5 \mathrm{MPa}>369,7 \mathrm{MPa} .
\end{aligned}
$$

The condition is not satisfied, that's why column bases may not be classified as rigid; this column base is semi-rigid.

\section{CONCLUSION}

A mathematical model of shakedown and optimization of thin-walled metal plane frames, which elements are from 1 st to 4 th class cross-sections, under variable repeated uncertain loads, was proposed. 
The problem of the discrepancy between the classification of the column base and the modeled joint in the design model was noted. Some ways of solving this task are suggested, namely, increasing the rigidity of the column base.

The rotational stiffness of a column base might be increased by adding the bracing system, which can reduce the horizontal displacement by at least $80 \%$, increasing the number and diameter of bolts, strength of concrete foundation, thickness of base plate and etc.

The numerical example was demonstrated. In the formulation of the problem proposed there might be included minimization of weight of the metal amount for the column base taking into account the rigidity of foundation.

\section{REFERENCES}

1. Eurocode 3 EN 1993-1-3: Design of steel structures. Part 1-3: General rule. Brussels, European Committe for standardizations, 2006.

2. Eurocode 3 EN 1993-1-1: Design of steel structures. Part 1-1: general rules and rules for buildings, Brussels, European Committe for standardizations, 2006.

3. Eurocode 3 EN 1993-1-8: Design of steel structures. Part 1-8: Design of joints. Brussels, European Committe for standardizations, 2010.

4. Alawdin P.: Limit Analysis of structures under variable loads, Minsk, Tekhnoprint 2005.

5. Alawdin P, Liepa L.: Optimal shakedown of the thin-wall metal structures under strength and stiffness constrains, in: Civil and environmental engineering reports - CEER 2017; 25 (2): 25-41.

6. Atkočiūnas J.: Optimal shakedown design of elastic-plastic structures, Vilnius, Gediminas Technical University, 2012.

7. Żukowski S.: Safety estimation of the plane bar structures based on the shakedown theory point of view, Wrocław, Publishing house of Wrocław Technical University, 2006.

\section{ANALIZA NOŚNOŚCI GRANICZNEJ RAM CIENKOŚCIENNYCH PRZY UWZGLĘDNIENIU SZTYWNOŚCI ICH FUNDAMENTÓW}

\section{Streszczenie}

W artykule przedstawiono model matematyczny problemu optymalizacji nośności granicznej oraz przystosowania dla ram cienkościennych metalowych pod obciążeniem wielokrotnie zmiennym. Autorzy zakładają sprężysto-plastyczne wyboczenie przy zginaniu w jednej płaszczyźnie, bez poprzecznego skrętnego wyboczenia elementów przy 
idealnie sprężysto-plastycznym odkształceniu materiałów ram. Zgodne z ustaleniami EuroCode, zostały opisane cechy charakterystyczne takich ram, biorąc pod uwagę sztywność ich fundamentów. Przeanalizowano problem definicji ekwiwalentnego jednorodnego współczynnika momentu dla ram przy obciążeniu wielokrotnie zmiennym, kiedy wykres momentów nie jest stały. Przeanalizowano również klasyfikację połączeń w zależności od ich sztywności. Opisano przypadki, w których nie zostały spełnione warunki sztywności. Opracowano warianty rozwiązywania takich zadań dla ram cienkościennych metalowych, dla których istnieje rozbieżność między początkowym i rzeczywistym modelem obliczeniowym sztywności. Zostało to przedstawiono na zasadniczym schemacie procesu iteracji. Na przykładzie numerycznym przedstawiono problemy, związane z uwzględnieniem sztywności połączeń na ostatnim etapie optymalnego projektowania metalowych ram cienkościennych.

Słowa kluczowe: nośność graniczna oraz przystosowanie, model matematyczny, metalowe ramy cienkościenne, sztywność fundamentów

Editor received the manuscript:05.03.2018 